\title{
5 \\ Putting the cartel before the house? Public funding of parties in Queensland
}

\section{Graeme Orr}

In the cartel thesis of party behaviour, parliamentary parties have incentives to forget their political rivalry and cooperate on electoral reforms. This is especially so between the major parties in majoritarian electoral systems like those in Australia. In the political finance realm, the hypothesis is that the dominant parties will seek to featherbed themselves and minimise competition from alternative players. The cartel idea is not that these motivations necessarily override all principles or competitive instincts or that they are universal irrespective of conditions, ${ }^{1}$ but that cartel-like behaviour can be expected. A prime example is the maintenance of majoritarian voting systems themselves.

This chapter presents a subnational case study to examine why public funding is adopted and the strength of the cartel thesis in explaining the political and legislative dynamics of its evolution. Political finance laws at the subnational level in Australia have been a source of innovation in recent years, despite the law barely evolving in over 30

1 Richard S. Katz and Peter Mair (2012) 'Parties, Interest Groups and Cartels: A Comment', Party Politics 18(1): 107. 
years at the national level. ${ }^{2}$ This chapter considers the curious case of the State of Queensland. Queensland, it must be acknowledged, presents a somewhat special case in lacking an upper house. ${ }^{3}$ With a unicameral parliament, and not needing to consult let alone negotiate with other parties in the design of the legislation, governments can legislate with impunity.

Party regulation in Queensland presents a fairly naked example of incumbency advantage with aspects of cartel behaviour. Queensland has veered from mimicking the Commonwealth's lighttouch political finance regulation to highly regulated and back to light regulation in barely one electoral cycle (2011-14). In each of these instances of reform, first an Australian Labor Party (ALP), then a Liberal National Party (LNP) government, has driven through public funding provisions whose generosity has suggested rent-seeking. ${ }^{4}$ The LNP reforms also included egregious elements discriminating against minor parties and Independents, suggesting duopolistic behaviour. Yet such cartelism is not inevitable, as is revealed when the Queensland approach is compared with contemporaneous reforms in other States. This reinforces Ekaterina Rashkova and Ingrid van Biezen's insight that while governing parties may have cartelistic or featherbedding motivations in adopting public funding, that is certainly not its necessary effect. ${ }^{5}$

\section{Public funding of political parties}

Public funding of parties has returned to the forefront of debate about institutional reform and the law of politics in Australia. Ostensibly, this has been driven by party finance scandals centred on New South

2 Graeme Orr (2016) 'Political Finance Law in Australia: Innovation and Enervation', Election Law Journal 16(1): 58-70.

3 See Nicholas Aroney, Scott Prasser and J. R. Nethercote (eds) (2008) Restraining Elective Dictatorship: The Upper House Solution, Perth: UWA Press.

4 On rent-seeking, see Ingrid van Biezen and Petr Kopecký (2007) 'The State and the Parties: Public Funding, Public Regulation and Rent-Seeking in Contemporary Democracies', Party Politics 13(2): 235.

5 See footnote 69 , this chapter. 
Wales (NSW), ${ }^{6}$ which triggered proposals to ban private donations in favour of full public funding of parties. Indeed both ALP and Liberal Party leaders, in NSW at least, have backed full public funding, at least of elections, as have other conservative leaders. ${ }^{7}$ Full public funding, however, has not attracted the support of experts and is unlikely to eventuate for a mix of practical and constitutional reasons. ${ }^{8}$

Nonetheless, this turn towards embracing more public funding represents a pivot away from traditional cynicism concerning taxpayer support. Such cynicism permeated public and media debate in earlier decades. In some cases, it succeeded in blocking moves to introduce public funding (as was the case, until recently, in Western Australia); in other cases, it succeeded in blocking proposals to increase funding (for instance, the Commonwealth Government withdrew a Bill to increase funding in May 2013, when the Opposition reneged on its support in the face of public unease). It is timely, then, to consider the origins, rationales and nature of public funding of parties.

There is not space here to detail the different funding regimes across Australia; this has been done elsewhere and is discussed in Chapter 1 of this volume. ${ }^{9}$ Public funding, aka state subsidies or subventions, has taken a number of guises in Australia. These various methods have been justified on the basis of injecting 'clean' money into the political system. But each method has also involved elements of rewarding the stronger - whether it be the electorally successful or the parties most able to attract donors. The predominant guise for public funding has been direct grants to parties in the form of post-election payments.

6 NSW Independent Commission Against Corruption (ICAC) (2014-15) NSW Public Officials and Members of Parliament - Allegations Concerning Corrupt Conduct involving Australian Water Holdings Pty Ltd (Operation Credo) and Allegations Concerning Soliciting, Receiving and Concealing Payments (Operation Spicer), Sydney: ICAC, available at: icac.nsw.gov.au/investigations/currentinvestigations/investigationdetail/203.

7 Premier Baird (Liberal) endorsed the idea, previously floated by Premier Iemma (ALP) and supported in principle by Opposition Leader Robertson (ALP): Geoff Winestock and Scott Parker (2014) 'Baird Announces Donations Crackdown but Not Until 2015', Australian Financial Review, 28 May: 6. In 2015, both the LNP Opposition Leader in Queensland and the Country Liberal Party Chief Minister of the Northern Territory embraced the idea as well.

8 Department of Premier and Cabinet, Panel of Experts ['Schott Inquiry'] (December 2014) Political Donations: Final Report. Volume 1, Sydney: NSW Government, Ch. 4. See also George Williams (2014) 'Public Funding of Elections is Costly and Simply Unfair', Sydney Morning Herald, 3 June: 18; and Joo-Cheong Tham (2014) 'Don't Ban Political Donors', Australian Financial Review, 7 May: 43.

9 See Joo-Cheong Tham (2010) Money and Politics: The Democracy We Can't Afford, Sydney: UNSW Press, Ch. 5; and Orr, 'Political Finance Law in Australia', pp. 61-2, Appendix. 
This has typically been available on a 'dollars per vote' basis, subject to a minimum vote share. As we will see, other models include reimbursement on a sliding scale of actual campaign expenditure and annual 'administration' funding throughout the parliamentary cycle, depending on the party's success in having Members of Parliament (MPs) elected.

Other forms of taxpayer support for parties are not tied to electioneering. One involves income tax deductions for donations - a federal rule that treats registered parties as quasi-charities to encourage smaller-scale donations as a form of political participation. ${ }^{10}$ The other involves extra staff and allowances to MPs and parliamentary caucuses, as well as Commonwealth funding of party think tanks and international activity. ${ }^{11}$ These supports are directed to the parliamentary wing of the party, rather than its administrative wing, and exist ostensibly to enhance legislative and constituency work. But they are relevant to party organisations as their benefit bleeds back to the party as a whole and its electoral advocacy.

\section{The dawn of public funding in Australia}

For 20 years, Queensland law has formally allocated some taxpayer funding to State political parties or candidates. From 1994 until 2011, those laws were simple and stable. They borrowed directly from the Commonwealth model - begun in 1983 but which itself drew from the pioneering NSW system of $1981 .^{12}$ A party or candidate that achieved 4 per cent of the vote in a seat qualified for payment for those votes. That model was based on the idea of partial funding of electoral campaigns.

\footnotetext{
10 There is partisan contention about the level of taxation relief and its application to corporate as opposed to individual donors. Deductibility applies to the first $\$ 1,500$ per annum and corporate donors are included.

11 On the latter type of funding, see Chapter 1, this volume.

12 Ernest Chaples (1981) 'Public Campaign Finance: New South Wales Bites the Bullet', Australian Quarterly 53(1): 4. The NSW scheme was capped so no party could receive more than 50 per cent of the funding, however electorally successful. It later expanded to include annual funding to defray parties' administrative costs.
} 
Money thus can be 'earned' for every first preference vote received. For Commonwealth elections, the funding rate has grown more generous over time, as shown in Figure 5.1. The first Commonwealth public funding regime was tied to the basic postal rate- 90 cents per elector per election, or three stamps' worth $^{13}$ - as if campaigning was still paper-based, as in the United Kingdom.

But since the major cost of Australian electioneering has long been broadcast advertising, the level of public funding was unsurprisingly ratcheted up. The biggest increase came in the 1990s, when funding for a Senate vote was raised to equal that for a House of Representatives vote. This not only increased the overall pool of funds, it also helped minor parties, as they do better at Senate than House elections and they tend not to attract business donors. Similarly, Queensland public funding rates over time rose from $\$ 1$ to well over $\$ 2$ per vote (remembering that in unicameral Queensland, electors have a single vote and there are no upper house campaigns to fund). After each triennial State poll, moneys were thus paid to defray electioneering expenditure. Unlike national elections, Queensland persevered with a 'reimbursement' requirement that calls for receipts of actual expenditure. ${ }^{14}$

Queensland's adoption of public funding in 1994 stemmed from the recommendation of the independent Electoral and Administrative Review Commission. ${ }^{15}$ This followed a major anticorruption Royal Commission report, which included concerns about the possibility of improper favour being shown or being seen to have been shown by the government to political donors' ${ }^{16}$ A longstanding conservative Coalition Government was found to have presided over corruption in the police force. There was also evidence of businessmen making cash donations directly to the premier and to the secretary of the National Party, both to assist the governing party and to influence factional battles within it. After the fall of that Coalition Government,

\footnotetext{
13 I. C. Harris (1984) 'The Australian Joint Select Committee on Electoral Reform', The Table 52: 52.

14 This avoided occasional windfall profits.

15 Electoral and Administrative Review Commission (EARC) (1992) Investigation of Public Registration of Political Donations, Public Funding of Election Campaigns and Related Issues, Brisbane: EARC.

16 G. E. 'Tony' Fitzgerald QC ['Fitzgerald Inquiry'] (1989) Commission of Inquiry into Possible Illegal Activities and Associated Police Misconduct, 1989: Report, Brisbane: Queensland Government.
} 
the new ALP administration supported public funding, ${ }^{17}$ while the Liberal and National parties at the time opposed it as an 'attack on the fundamental freedom of the individual'18 and a 'pollie tax'. ${ }^{19}$ In this, the conservative parties were repeating their position on the introduction of Commonwealth public funding: they opposed it on principle, but would share in it once enacted. ${ }^{20}$

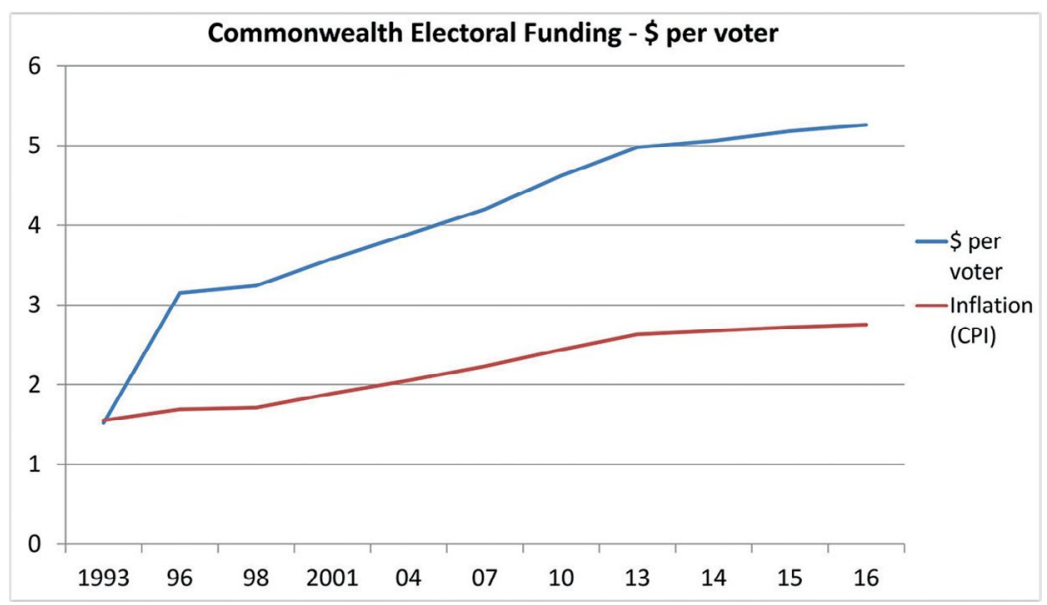

Figure 5.1 Growth in public funding rate (Commonwealth elections) Source: Australian Electoral Commission.

\section{Public funding's three rationales: Resourcing parties, dampening demand for private money and political equality}

A pragmatic intention of public funding was to ensure parties were adequately resourced. Public funding was introduced in Queensland only because a short-lived nationwide ban on paid broadcast election

17 Parliamentary Committee on Electoral and Administrative Review (PCEAR) (1993) Investigation of Public Registration of Political Donations, Public Funding of Election Campaigns and Related Issues, Report No. 20, November, Brisbane: Queensland Parliament.

18 ibid., para. 3.12. That said, the Opposition was more concerned to champion the rights of union members to not indirectly fund the ALP than it was to oppose public funding (paras 3.13-19).

19 Denver Beanland (Liberal), Queensland Parliamentary Debates, 24 November 1994, p. 10,809 .

20 Joint Select Committee on Electoral Reform (JSCER) (1983) First Report, September, Canberra: Parliament of Australia, paras 9.11-9.17. 
advertising did not survive constitutional challenge. ${ }^{21}$ The loss of that ban - a measure meant to dampen the cost of electioneering — was said to justify public funding by helping to bridge the cost of campaigning and sources of finance. This bears out Anika Gauja's insight that, around the world, public funding has been 'introduced, in part, as a mechanism to ensure parties' survival in electoral democracies characterized by increasing campaign costs and declining party memberships' ${ }^{22}$ It is also consonant with Zim Nwokora's observation that parties - understood as ongoing entities as opposed to temporary legislative majorities - seek institutional measures that give them organisational security and predictability. ${ }^{23}$ Ideally, public resourcing of parties contributes to their institutional strength, and is not simply a crutch for the major parties. It can assist in maintaining a viable opposition party through lean years, as well as helping minor parties build capacity and hence sustain interparty competitiveness.

Along with public funding, the contemporaneous introduction of mandatory disclosure of larger donations and loans in Queensland was also expected to dampen the 'supply' of private funds. ${ }^{24}$ The focus of reform was thus on the revenue side of party activities within a free 'market' for political money. Debate about capping electoral expenditure or donations would not emerge seriously until the late 2000s. This was despite caps on expenditure having been imposed on Australian candidates for nearly a century until the $1970 \mathrm{~s},{ }^{25}$ being part of the opt-in system of public funding of US presidential campaigns and applied to Canadian parties since 1974.

Public funding was initially understood as a quid pro quo for the obligation to disclose donations and loans (although such disclosure applied to all parties, including small parties who would not benefit from public funding). Disclosure, conversely, was seen as an 'essential

\footnotetext{
21 EARC, Investigation of Public Registration of Political Donations, para. 4.83.

22 Anika Gauja (2010) Political Parties and Elections: Legislating for Representative Democracy, Farnham: Ashgate, p. 162.

23 Zim Nwokora (2014) 'The Distinctive Politics of Campaign Finance Reform', Party Politics 20(6): 918.

24 EARC, Investigation of Public Registration of Political Donations, p. 111.

25 Deborah Cass and Sonia Burrows (2000) 'Commonwealth Regulation of Campaign Finance: Public Funding, Disclosure and Expenditure Limits', Sydney Law Review 22(4): 477, 484-5 and 491-2.
} 
corollary' of public funding: ${ }^{26}$ the shining of sunlight on to private money in tandem with the injection of 'clean', no-strings-attached public money. Unlike disclosure, public funding makes almost no organisational demands on party organisations. In that sense, it poses no immediate questions for the freedom of political association.

Public funding, however, does indirectly risk corrosion of the internal vitality of parties as forums for political participation. Echoing Nwokora's observation that party administrators have a strong interest in the financial security of their party as an entity, reliance on external sources of funding - whether it be overly generous public funding or corporate largesse - may exacerbate the atrophying of parties' grassroots connections (a risk raised by the professionalisation of party administration and centralisation of policy control in parliamentary leaderships). It is difficult, however, to measure the organisational effects of parties becoming overly reliant on public funding. In the absence of full public funding year in and year out, and given the reputational and financial costs of hiring 'supporters', Australian parties still need members to leaflet households during campaigns and at polling stations. Constituency campaigns can also benefit from mobilising members as local fundraisers. If nothing else, if public funding were generous enough to wean parties from overreliance on institutional donors, it should also shore up the influence of individual party members as opposed to outside donors.

Aside from helping secure party resources, the more noble aims of public funding relate to political integrity and equality. In (over)selling the introduction of public funding of parties at the Commonwealth level, Minister Beazley claimed its cost was 'a small insurance to pay against the possibility of corruption' and that it 'ensures that different parties offering themselves for election have an equal opportunity to present their policies to the electorate' ${ }^{27}$ Ideally, public funding inhibits demand for large-scale private donations and can create a more level playing field..$^{28}$ In Australia as a whole, it has not worked well on the integrity measure, because of a lack of expenditure caps to inhibit growth in electioneering expenditure or donation caps generally.

26 Kim Beazley (ALP), House of Representatives Parliamentary Debates, 2 November 1983, p. 2215.

27 ibid.

28 EARC stressed the rationale of levelling the playing field: EARC, Investigation of Public Registration of Political Donations, paras 4.9, 4.15. 
Parties therefore still seek large donations, with the attendant risk and perception of the buying of influence. Public funding, however, has worked somewhat better in tempering the inequality between incumbents and outsiders, and between larger and smaller parties.

\section{Political equality in the Queensland party context}

Commentators such as Tham have criticised existing means of public funding as 'both ineffectual and unfair'. ${ }^{29}$ The 'unfairness' criticism may be overstated. Fairness must also consider citizen concerns about taxpayers' money being directed into partisan politics. Election funding per vote is at least simple for citizens to comprehend, and fair in the sense that dollars follow their first-preference voting choices ${ }^{30}$ (what US reformers call 'voting with vouchers' or 'voting with dollars'). ${ }^{31}$ Opposition parties, which attract fewer business donations than governments, ${ }^{32}$ can 'bank' on a certain level of funding, and the more popular minor parties and Independents are also catered for. ${ }^{33}$

While not amounting to affirmative action in favour of smaller parties - with the exception of microparties struggling to achieve the threshold to qualify for any funding - public funding in Australia has tended to be highly proportional to electoral support. After the 2009 election, for instance, the Queensland ALP and LNP each received almost 44 per cent of public funding (on approximately 42 per cent of the vote each), the Queensland Greens received almost 7.5 per cent of public funding (on just over 8 per cent of the vote) and Independents collectively did better than their combined vote share (as there are numerous locally popular Independents).

\footnotetext{
29 Tham, Money and Politics, p. 127.

30 JSCER, First Report, para. 9.27.

31 Bruce Ackerman and Ian Ayres (2002) Voting with Dollars: A New Paradigm for Campaign Finance, New Haven, Conn.: Yale University Press; Rick Hasen (1996) 'Clipping Coupons for Democracy: An Egalitarian/Public Choice Defense of Campaign Finance Vouchers', California Law Review 84(1): 1-59.

32 Iain McMenamin (2013) If Money Talks, What Does it Say? Corruption and Business Financing of Political Parties, Oxford: Oxford University Press, pp. 81-2.

33 On the importance of public funding for The Greens and Australian Democrats, see JooCheong Tham and David Grove (2004) 'Public Funding and Expenditure Regulation of Australian Political Parties: Some Reflections', Federal Law Review 32(3): 397-401.
} 
Such rewards are particularly important given Queensland's electoral system is otherwise stacked against smaller parties seeking to grow organically. There is a majoritarian voting system and no upper house. The Queensland Greens and Australian Democrats have never held a seat at State level, and minor party MPs have mostly come from groups splintering from established, especially conservative, parties. ${ }^{34}$

As Figure 5.2 shows, the Queensland Greens, despite having relatively robust grassroots, receive between 65 and 80 per cent of their revenue from public funding in years when it is available (typically after a State or Commonwealth election). This suggests even greater reliance on public funding than in the early 2000s when, Australiawide, The Greens and the Australian Democrats drew between 25 and 40 per cent of their revenue from public funding. ${ }^{35}$ As smaller parties consolidate, their share of public funding improves because their vote share reaches the threshold in more seats, but, unless they acquire the balance of power and attune their ideology to that of corporate or union donors, they cannot attract big donations. ${ }^{36}$

While Queensland's electoral system is harsh on minor parties, its sociodemography is kinder on Independents, who often flourish in Queensland's decentralised regions. State-level examples such as the Independent MPs for Nambour and Gladstone have held their seats for over 15 years and increased their majorities in the process. Independents elected to regional Queensland seats at the federal level-Pauline Hanson (Ipswich), Bob Katter (north-western Queensland) and Clive Palmer (Sunshine Coast) - have even leveraged their status to found national political movements. Public funding was framed in Queensland, as it was nationally, with the parties insisting on controlling the funding through direct payments to them, rather than to the candidates who at least notionally 'earned' it. But Independent candidates were nonetheless entitled to funding on an equal basis.

\footnotetext{
34 The Queensland Labor Party and even North Queensland Labor Party in the 1950s and One Nation (which splintered into a City-Country Alliance) in the late 1990s. Today's Katter's Australian Party and Palmer United Party are named after founders who served with the old National Party and each has relied on poaching LNP MPs.

35 Marian Sawer, Norman Abjorensen and Phil Larkin (2009) Australia: The State of Democracy, Sydney: The Federation Press, p. 113; and Tham and Grove, 'Public Funding and Expenditure Regulation of Australian Political Parties'.

36 There are exceptions, such as philanthropist-entrepreneur Graeme Wood's record, one-off \$1.6 million gift to The Australian Greens in 2010 .
} 


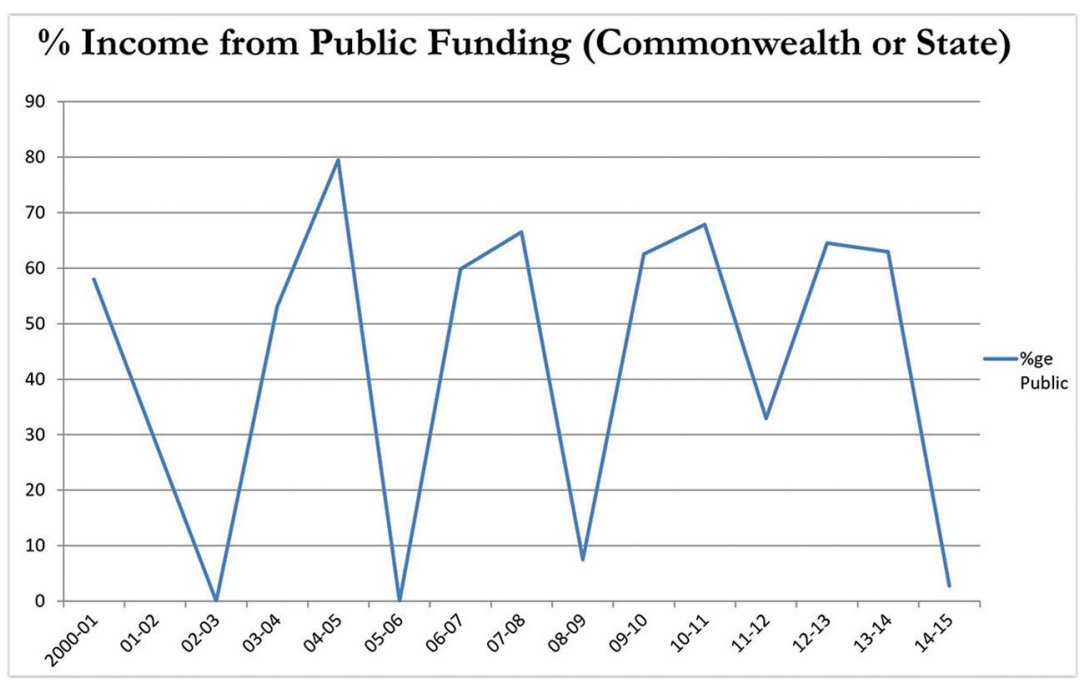

Figure 5.2 Queensland Greens' income from public funding Sources: Australian Electoral Commission and Electoral Commission Queensland.

\section{Sweeter carrots, sharper sticks: The 2011 Queensland ALP reforms}

By 2011, after the best part of two decades in power and under Australia's first elected female premier, the Queensland ALP Government was coming to an end. It faced an election no later than March 2012, with opinion polls predicting a shellacking. (That wipeout came to pass. The party won just seven of 89 seats and garnered under 27 per cent of the primary vote.) It had encountered criticism, including from former corruption-fighting Royal Commissioner Tony Fitzgerald, about a slippage in ethics and integrity in government, including the purchase of political access. ${ }^{37}$ Premier Bligh responded with a discussion paper, Integrity and Accountability in Queensland, in August 2009. Besides a self-imposed ban on ministers selling access by attending fundraising functions, ${ }^{38}$ the paper suggested limiting

37 Tony Fitzgerald QC (2009) Introductory Address: Inaugural Griffith University: Tony Fitzgerald Lecture, available at: griffith.edu.au/_data/assets/pdf_file/0020/156125/TonyFitzgerald---Arthurs-introduction---Griffith-lecture-web.pdf.

38 See Brian Costar (2014) Selling Access to Elected Officials: Beyond Regulation?, Paper presented to the Academy of the Social Sciences in Australia Workshop: The Legal Regulation of Political Parties in Australia, University of Sydney. 
electioneering expenditure and briefly flagged an intention to cap donations, explicitly implying a compensatory increase in public funding. ${ }^{39}$

What ensued was a long period of brainstorming and policymaking within the government, and some public discussion, before the release of a White Paper, Reforming Queensland's Electoral System, in December 2011.40 The White Paper outlined a legislative model that appeared in a Bill several months later. The model revolved around:

a. tightening disclosure (which the ALP had already made more regular)

b. capping donations to parties to $\$ 5,000$ per annum from a single source (at least for campaign as opposed to administrative purposes)

c. capping electioneering expenditure for parties and interest groups

d. dramatically increasing public funding.

NSW had, a year earlier, moved to cap donations and election expenses, as did the Australian Capital Territory (ACT) in 2012.41 Queensland's reforms erected a first in Australian political history: an eastern State wall of comprehensive political finance schemes. ${ }^{42}$ Queensland borrowed significantly from the NSW regime at the time, particularly (as the next paragraph explains) the idea of guaranteeing a percentage of election campaign costs. A Queensland innovation, however, was to cap only donations that were fed into a State or local government campaign account. State law, for constitutional reasons, cannot regulate donations to Commonwealth election campaigns. NSW, however, had gone further, and capped donations that funded party administration, not just campaigning. The Queensland exception was a way around two sticking points. Union contributions were one, and they remained uncapped insofar as they supported ALP administration rather than campaigning. The other was the fact that, at the time, a billionaire by the name of Clive Palmer was helping bankroll the LNP (as noted above, Palmer has since founded his own party and became a federal MP).

39 Queensland Government (2009) Integrity and Accountability in Queensland, August, Brisbane: Queensland Government, pp. 14-15.

40 Election Funding and Disclosures Amendment Act 2010 (NSW).

41 Electoral Amendment Act 2012 (ACT).

42 National laws remain light-touch: Graeme Orr (2010) The Law of Politics: Elections, Parties and Money in Australia, Sydney: The Federation Press, pp. 239-40, 256-8. 
In the 2011 reform, public funding was sweetened indeed, especially from the perspective of Queensland's major parties. A sliding scale for reimbursement of certain campaign expenditures replaced funding per vote. The scale was generous: up to 75 per cent of the capped expenditure limit for centralised party spending and up to 52.5 per cent of the limit for candidate-level expenditure. ${ }^{43}$ As only the major parties normally ever approach those caps, the system would reinforce their financial and hence campaign dominance. Yet smaller parties could benefit over their previous position, provided they could attract well-off donors or guarantors. Hence the system was potentially more competitive than one based purely on vote share. Katter's Australian Party, a populist agrarian party, benefited when it received almost $\$ 1.4$ million in 2012-over 9 per cent of the total public funding, which was less than its vote share of 11.5 per cent but $\$ 850,000$ more than it would have received under the dollars-per-vote scheme.

The new model also permitted 'advance payments' of public funding of up to 50 per cent of previous electoral entitlements. ${ }^{44}$ This formed a particular benefit to the established parties and MPs, helping them rely on public funding rather than having to raise sizeable donations or loans upfront.

In another borrowing from NSW, biannual funding of parties' administrative activities was introduced. The Queensland minister sought to justify the significant increases in overall funding in familiar terms, appealing to resourcing ('it is expensive to have an election and it is expensive to have a democracy') and integrity (campaigning 'costs money - money which can come from either wealthy benefactors with special strings attached or public funding' $).{ }^{45}$

The Opposition and crossbenchers were not consulted in this policymaking process. ${ }^{46}$ The government consulted only the Electoral Commission. The timing of the White Paper, released on Christmas Eve, was not auspicious for debate. Public submissions closed in mid-

43 Electoral Accountability Amendment Act 2011 (Qld), introducing new sections 177DA-DB to the Electoral Act 1992 (Qld).

44 ibid., introducing new section 177DC to the Electoral Act 1992 (Qld).

45 Paul Lucas (ALP), Queensland Parliamentary Debates, 11 May 2011, p. 1416.

46 Jarrod Bleijie (LNP), Queensland Parliamentary Debates, 11 May 2011, p. 1413 ('This bill is a beast of the Labor Party that we had no input into and the Independents had no input into'). 
February. The poor timing was exacerbated by floods that devastated most of the State in late January. Only nine public submissions were received, and none was published.

The ALP's reform Bill was tabled in parliament for a month. Yet despite its complexity (it contained 90 pages of new political finance law alone), it was not subject to any committee scrutiny. The government then pushed the Bill through, subject to a series of intricate amendments, in a single afternoon/evening's debate.

The conservative Opposition objected to the Bill as a whole. It argued that an increase in public funding was not justified (especially as the State rebuilt after the floods) and that the Bill had been hastily drafted. It specifically objected to party funding on a reimbursement scale, arguing that minor parties might disproportionately benefit ${ }^{47}$ an argument that assumed minor parties could bankroll sizeable campaigns in the first place. For their part, the Queensland Greens objected to the Bill as a windfall for the major parties. The new stream of administrative funding was available only to parties with MPs or to Independent MPs. Even so, the five Independent MPs voted against the Bill. In 2011-12, the new stream of administrative funding added $\$ 4.16$ million in public funding, ${ }^{48}$ most of it to the two major parties.

While the caps in the Bill conformed to social-democratic principles, there was widespread suspicion that the enhanced public funding and its generous sliding scale were a boondoggle for an ALP government facing electoral oblivion. As that wipe-out came to pass, the ALP still received \$6 million in public funding - over five times the amount it would have received under the funding-per-vote system. It received 40 per cent of total public funding on not quite 27 per cent of the vote. The LNP received over 44 per cent of the funding on not quite 50 per cent of the vote. In all, \$15.14 million was paid out for that election. ${ }^{49}$ The minor parties did less well in their relative share of funding, but the rising tide of funding meant that, in absolute terms, all parties and candidates were better off.

47 ibid., p. 1423.

48 Electoral Commission Queensland (ECQ) (2012) 2011-12 Annual Report, Brisbane: ECQ, p. 12.

49 Electoral Commission Queensland (ECQ) (2013) 2012-13 Annual Report, Brisbane: ECQ, p. 6. 


\section{No quid pro quo: The 2014 Queensland LNP reforms}

On assuming power with an Australian record seat share of nearly 88 per cent, the newly elected conservative government moved quickly to repeal the regular administrative funding of parties. It did so before the end of 2012, as a cost-saving measure to address what it said were 'outrageous' payments to political parties. On 3 January 2013, it released the Electoral Reform Discussion Paper..$^{50}$ The paper read like a bland issues paper, without indicating the government's thinking on reform. Approximately two months were allowed for public submission. Unlike its predecessor, at least the new government published all 254 of the submissions.

In July 2013, the LNP Government played some of its hand. Its Electoral Reform: Queensland Electoral Review Outcomes paper recommended a complete revamp of the Queensland political funding landscape $\mathrm{e}^{51}$ - for the second time in three years. Consistent with libertarian philosophy, the government proposed abandoning limits on political donations and electoral expenditure. It toyed with more regular disclosure of donations, but soon reversed this position, citing timorous legal advice that States could not demand more information from their political parties than the national laws required. (Timorous, because there is no difficulty in complying with a Commonwealth disclosure system and a more revealing State disclosure system. In fact, constitutional principle requires that each level of government retains some autonomy over its own electoral system because that system is integral to its existence as a body politic. $)^{52}$

On public funding, the sliding scale of reimbursement of party electioneering expenditure was returned to the traditional dollarsper-vote model. Just as the sliding scale had insulated the ALP through its calamitous loss of support in the 2012 election, undoing it would pose difficulties for the ALP until its vote share was repaired.

50 Department of Justice and Attorney-General (2013) Electoral Reform Discussion Paper, January, Brisbane: Queensland Government.

51 Department of Justice and Attorney-General (2013) Electoral Reform: Queensland Electoral Review Outcomes, July, Brisbane: Queensland Government.

52 ACTV v Commonwealth (1992) 177 Commonwealth Law Reports, pp. 163-4. See also Local Government Association (Qld) v Queensland [2001] QCA 517, paras 47, 69-70. 
The government also proposed raising the vote share threshold to earn public funding to 10 per cent. This measure was guaranteed to nobble the three significant minor parties in Queensland: the Queensland Greens, Katter's Australian Party and (to a lesser extent, since its founder was a billionaire) the emerging Palmer United Party. When it was introduced in late November 2013, the Bill went further in discriminating against the minor parties by providing that Independents receive post-election funding at half the rate of the parties - $\$ 1.45$ compared with $\$ 2.90$ per vote. If anything, Independents' campaigns may need higher rather than lower funding, as they lack the economies of scale and expertise of party campaigns.

The Bill also proposed reintroducing funding of the parties in nonelection years, just a year after it had been abolished. This policy reversal had not been canvassed in the public consultations. It was to be denied not only to parties without MPs, but also to Independent MPs. The measure was dressed up as 'policy development funding'. Unlike the NSW or the former Queensland schemes for administrative funding, there was no limit on a single party dominating the fund. In fact, during the life of the then parliament, the LNP would receive the majority of funds (as this new layer of funding was to be based on vote share in the previous election). Also unlike the NSW or former Queensland schemes, there were no strings attached: this funding can be squirrelled away for electioneering.

Most remarkably of all, in an Australian first, the amount of funding would be set neither by parliament nor by an index, but by the Attorney-General from time to time. To the government's credit, it seemed genuine in wishing to significantly reduce the total amount of party funding, from a potential $\$ 23$ million over a three-year electoral cycle under the ALP's short-lived scheme. How much that is reduced will, however, depend on the parsimony of each attorney-general. In addition, the free market in donations was made retrospective to the tabling of the Bill, and the raising of disclosure levels was also made retrospective to the previous financial year. The major parties, and especially the incumbent government, could begin building war chests for the 2015 election - an election in which campaign expenditure would once again be unlimited. 
The Bill was scrutinised by a committee dominated, given the makeup of parliament, by government MPs (five to two). The committee consulted over the Christmas-New Year period and received 180 submissions. It held a brief public hearing (one morning, on a day devoted to numerous, unrelated Bills) and delivered a report that was split on party lines..$^{53}$ However, on one point, government members rebelled, calling for the threshold to earn electoral funding to be raised not to 10 per cent but to 6 per cent. The government agreed to that softening of the negative impact of the funding reform on minor parties and Independents.

Outside the government, responses to the new political funding proposals were largely negative. ${ }^{54}$ Yet the ALP Opposition voted with the LNP Government in favour of discriminating against Independents in the post-election and annual 'policy development' funding schemes, and in not attaching conditions to the use of public funding. ${ }^{55}$ The ALP also supported backdating the funding laws to the previous financial year. ${ }^{56}$ On neither matter did the ALP or the government seek to justify its position to parliament. The ALP did, however, express opposition to raising the threshold to earn post-election funding to 6 per cent, arguing it was unfair on smaller players. ${ }^{57}$

In contrast, all the crossbenchers - a group collectively larger than the official ALP Opposition-vociferously opposed the enhanced public funding measures. The disparate treatment of Independents and moves to reduce election funding of minor parties were said to be 'offensive in the extreme' and reason to be 'disgusted'. ${ }^{58}$ Annual 'policy development' payments favouring the major parties were a 'joke', 'disgusting' and a criteria-free 'slush fund'. ${ }^{59}$ The funding

53 Legal Affairs and Community Safety Committee (2014) Electoral Reform Amendment Bill, Report No. 56, February, Brisbane: Parliament of Queensland.

54 Supporting a free market in donations and expenditure, but tight disclosure of both, see: Anthony Gray (2014) 'Political Finance Regulation is a Field Strewn with Pitfalls', The CourierMail, 19 May: 20.

55 Queensland Parliamentary Debates, 22 May 2014, pp. 1858-61.

56 ibid, p. 1870.

57 Annastacia Palaszczuk (ALP), Queensland Parliamentary Debates, 21 May 2014, pp. 1738-9; and 22 May 2014, p. 1858.

58 Liz Cunningham (Independent) and Shane Knuth (Katter's Australian Party), Queensland Parliamentary Debates, 22 May 2014, pp. 1833-4 and p. 1842, respectively.

59 Ray Hopper (Katter's Australian Party), Alex Douglas (Palmer United Party) and Peter Wellington (Independent), Queensland Parliamentary Debates, 22 May 2014, p. 1813, pp. 1840-1 and p. 1861, respectively. 
scheme overall was said to 'target minor parties ... that want to grow organically' and undermine the important role of Independents. ${ }^{60}$ These voices represented two minor parties (Katter's Australian Party and the Palmer United Party) and a brace of regional Independents. The Greens, though they represented around 7 per cent of Queensland voters, lacked a parliamentary voice; they also opposed the new law. One government MP spoke against and abstained from voting for the laws, arguing that true liberalism required better disclosure and capping of donations. A day later, he resigned from parliament, citing the electoral finance laws as one reason he could not continue serving under the LNP. ${ }^{61}$

In comparison with the 2012 election, the amount of election funding paid in 2015 reduced considerably, to $\$ 10.75$ million. Of this, the two major parties received 86.23 per cent of the public funding, in fairly equal shares. The total amount of public funding was reduced, as promised; however, the minor parties suffered in two ways, due to the reduction in overall payments and because of the raising of the threshold to 6 per cent of the primary vote. ${ }^{62}$

\section{Public funding: Cleaning up parties or parties cleaning up?}

Philosophical leanings or principled ideological accounts of the public interest are far from irrelevant to questions about the law governing politics. They help ground debates about reform along fairly predictable lines: social-democratic parties tend to hew to egalitarian approaches and conservative parties tend to favour libertarian or free-market approaches. In Nwokora's account of the drivers motivating political finance law specifically, principled approaches are subject less to brute cartelism and more to a nuanced and sometimes dichotomous party self-interest. ${ }^{63}$ This dichotomy is not a distinction between parties of

60 Robbie Katter (Katter's Australian Party), Queensland Parliamentary Debates, 22 May 2014, pp. 1847-8.

61 Chris Davis (LNP), Queensland Parliamentary Debates, 22 May 2014, p. 1846. He had previously been sacked as an assistant minister for commenting against government policy.

62 The minor parties and Independents received just 13.77 per cent of public funding, despite collectively securing 21.21 per cent of the vote. Electoral Commission Queensland, Funding and Disclosure Director, Email to author, 12 April 2016.

63 Nwokora, 'The Distinctive Politics of Campaign Finance Reform', pp. 918-29. 
the left and right as such, but a contrast between the interests of the party machine - in securing long-term organisational security and minimising the financial risks of inevitable periods out of powerand those of the parliamentary caucus and their leaders to secure shorter-term incumbency benefits and electioneering advantage.

Electoral reform, of course, rarely happens without aligning with governing party self-interest, since governments are invariably in control of what passes through the lower house. Exceptions can occur in hung parliaments (as when the ACT Legislative Assembly imposed restrictions on government advertising in 2009). ${ }^{64}$ High-profile scandals also occasionally act as fillips to reform, forcing parties to act against their philosophical leanings and even self-interest. This can happen cataclysmically, as in Queensland after the governmental meltdown following the 1988 royal commission into corruption, or in an unfolding response to a series of corrosive revelations, as in NSW over recent years.

What insight into these various theories does the Queensland case study lend us? The initial period, until 1994, saw Queensland lagging behind the Commonwealth and NSW in not providing public funding for parties. This was explicable in terms of incumbency self-interest as well as the 'open-for-business' mentality of the long-term National Party-dominated government. The quasi-revolution of $1988 \mathrm{did}$ not immediately see the ALP use its majority to adopt public funding (unlike the ALP governments of 1981 in NSW and 1983 nationally). The Queensland ALP was well funded by a still numerically strong trade union movement and an investment fund; it was also pledged to honour the independent reform process.

But by 1994 pressures were building in the cost of campaigning, to the point that the ALP was happy to introduce public funding. The then conservative Opposition rejected it in principle, but did not fight for a 'right' to opt out of such funding. An implicit cartel-ish force can be seen at work here: the major party machines understood the security that public funding would bring, while their legislative wings appreciated the campaign support at a time when minor parties were rare in Queensland. 
In the significant but short-lived ALP reforms of 2011, a very obvious case of abuse of incumbency can be diagnosed. It manifested in a massive ramping up of public funding via a reimbursement of campaign costs and in the introduction of regular funding for party administration. This suited both the ALP's administrative wing and the about-to-be-ousted parliamentary team (which faced a rout and reliance on declining levels of union money at a time when corporate largesse was flooding back to an LNP that was on the verge of power). The 2011 reforms were also couched as egalitarian measures to limit campaign expenditure and the size of campaign donations, befitting social-democratic principles. But these came belatedly, after a long term in government. And even then, an exception was carved out for donations for party administrative purposes, to reassure the party machines. The LNP Opposition objected to the reforms, but once again happily shared in the money.

Back in power in 2012, the LNP Government moved quickly to undo administrative funding of parties, consistent with its fiscal conservatism. Yet within a year, it was restoring that regular pipeline of funding, and in a discriminatory form that breached the rule of law in two ways. One was by blatantly discriminating against Independent MPs and parties like the Queensland Greens; the other was by leaving the amount of administrative funding to fluctuate on the whim of a minister. The LNP also moved to deprive minor parties of post-election funding, by increasing the threshold by 150 per cent (from achieving 4 per cent to 10 per cent of the vote share) - an unprecedented move in Australia. Although it took its own backbench advice to reduce the increase to 50 per cent (from achieving 4 per cent to 6 per cent of the vote share), it insisted on halving the rate at which Independents earn such funding - a discrimination also unprecedented in Australia.

The conservative government and ALP Opposition split on predictable ideological lines on the question of caps on donations and party expenditure; however, the ALP Opposition supported the extra lines of public funding and did not oppose the discrimination against Independents. While the 2013-14 reforms were less hasty than the 2011 reforms, and the consultation process was better (it could hardly have been worse), in both cases the governing party acted in the certainty of a sizeable majority. In each instance, the Independents and minor parties opposed the reforms - even though the 2011 reforms, by increasing public funding, stood to benefit them. 
By 2015, the ALP had returned to power and a further review of the system was planned. It moved quickly to reinstate biannual disclosure of donations above $\$ 1,000$, and promised a broader review of the State's political finance system. The more moderate conservative Opposition leader (perhaps fearing a dearth of donations while in Opposition) surprised many by announcing his support for full public funding of parties' election campaigns. ${ }^{65}$ Perhaps these moves can lead to a lasting compromise and a stable model, but in the process Queensland will have embarked on three major overhauls of its party finance regime in barely five years. With a unicameral parliament, giddying legislative pendulums are, of course, far from unheard of.

In South Australia (SA), by contrast, across 2013, an ALP government expected to face defeat (a defeat that did not eventuate). Yet it combined with both its Liberal Opposition and The Greens, a key player in the upper house, to negotiate multipartisan political finance reform for the first time in modern Australia. The result was an opt-in public funding and expenditure limit system, with continuous donation disclosure but no donation caps. ${ }^{66}$ Tellingly, the public funding scheme, based on dollars per vote, was actually tilted towards, rather than against, newer and smaller players, with a higher value per vote allocated for the first 10 per cent of the votes received by parties without MPs.

Like Queensland, the Territories in Australia also have unicameral legislatures. The Northern Territory, partly due to its small demographics and budget, has never offered public funding. (With a small number of voters and a limited media market, its campaigns are cheaper and more localised.) Befitting its status as Australia's most social-democratic and bureaucratic jurisdiction, however, the ACT minority ALP Government enacted a detailed campaign finance regime in 2012, with Greens support. This included a $\$ 10,000$ donation cap, limits on campaign expenditure and relatively continuous disclosure of donations. The regime was built on an existing public funding scheme based on votes received. Yet within fewer than three years, the ACT ALP Government (still with minority status, but acting cartelistically with the Liberal Opposition's support) loosened

65 Australian Associated Press (AAP) (2015) ‘LNP to Consider Full Public Funding of Elections', Brisbane Times [Online], 29 May.

66 Electoral (Funding, Expenditure and Disclosure) Amendment Act 2013 (SA), taking effect from mid-2015. Aside from the lack of donation caps, the system resembles the much-vaunted New York City campaign finance model. 
the system by abolishing donation caps and reducing the frequency of disclosure. ${ }^{67}$ Remarkably, the public funding rate was quadrupled from $\$ 2$ to $\$ 8$ per vote - a perverse move given the abandonment of donation caps.

The multipartisan approach in SA and the process in NSW that has been driven by ongoing political scandals stand in contrast. The NSW process has not been entirely free of self-serving incumbent behaviour. The outgoing ALP Government imposed donation caps that did not apply to union affiliation fees; the incoming Liberal Government sought to crack down on contributions by unions (but fell foul of the High Court).$^{68}$ Nonetheless, driven by principle as well as by media and public pressure, parties in NSW have coalesced in agreeing on the desirability of a tightly regulated political finance system, overcoming conservative instincts towards libertarianism in political finance. The cartel aspects of Queensland's approach to public funding in recent years - putting the interests of the major parties before those of the broader interest of 'the house' or electoral balance - are thus not inevitable.

Ultimately, however, as the overall ramping up of public funding in Queensland and NSW's push for full public funding of campaign costs and even party overheads reveal, 'clean' public money can also be a way for parties to 'clean up'. This is not to say public funding is an evil. At least in the NSW model, with caps on donations and expenditure, the party finance system as a whole can seek to balance integrity, resourcing and equality aims. But while providing some stability for those minor parties that achieve significant popular support, thereby compensating for their difficulties in attracting sizeable benefactors, public funding in Australia (with the possible exception of the new SA system) has tended to reinscribe the privileged position of the major parties.

Reinscribing a privileged position, however, is not the same as cartelism. While rising levels of public funding may be a sign of professionalised parties becoming more dependent on state resources, public funding has overall been of significant assistance to minor

67 Disclosure was monthly and weekly in an election year; it is now quarterly, with weekly disclosure retained only in the three months before an election.

68 Unions NSW $v$ NSW [2013] HCA 58. 
parties in Queensland. Indeed, the State remains a fertile jurisdiction for the emergence of new parties. Paradoxically, smaller and newer parties may be more 'cartelised' - in the sense of dependent on public funding - than the major parties, but happily so. This reinforces Rashkova and van Biezen's finding that public funding, though it may stem from cartel or featherbedding behaviour, does not adversely affect the permeability of the party system to new entrants and competition. ${ }^{69}$

The drivers of political finance systems and their regulation are a mix of principles (liberal or social-democratic ideology), self-interest (both party machine and parliamentarians) and events (scandals and legislative curiosity and borrowings). The Queensland example has exhibited all of these factors, aside from obvious scandals. Cartel behaviour has manifested itself in amendments that short-changed minor parties and Independents and in featherbedding of public funding when it suited the major parties. Yet the story is as much one of normative rivalry between libertarian and collectivist positions, and of attempts by incumbents to balance their parliamentary interest in an incumbency advantage with their party machine's interest in the stability that enhanced public funding can bring.

69 Ekaterina Rashkova and Ingrid van Biezen (2014) 'Deterring New Party Entry? The Impact of State Regulation on the Permeability of Party Systems', Party Politics 20(6): 890-903. 
This text is taken from Party Rules?: Dilemmas of political party regulation in Australia, edited by Anika Gauja and Marian Sawer, published 2016 by ANU Press, The Australian National University,

Canberra, Australia. 